\title{
STUDI PENCEMARAN LOGAM BERAT MERKURI (Hg) DI PERAIRAN SUNGAI TABOBO KECAMATAN MALIFUT KABUPATEN HALMAHERA UTARA
}

\author{
Oleh:
}

Ainuddin, Widyawati

Email: $\underline{\text { ahmad_ainuddin@yahoo.co.id }}$

Dosen Fakulktas Ilmu Kelautan Universitas Nuku Tidore Maluku Utara

\begin{abstract}
ABSTRAK
Penelitian ini dilakukan untuk mengetahui kandungan logam berat merkuri $(\mathrm{Hg}) \mathrm{di}$ perairan Sungai Tabobo Kecamatan Malifut dan sekaligus untuk mengetahui kualitas air Sungai Tabobo Kecamatan Malifut Kabupaten Halmahera Utara.

Pengukuran parameter suhu, salinitas, $\mathrm{pH}$, oksigen terlarut dan kekeruhan menunjukkan bahwa kualitas perairan lokasi perairan masih layak untuk kehidupan bagi organisme perairan dan kandungan logam berat merkuri sangat kecil ditemukan yaitu dengan nilai rata-rata 0,00484 ppb.

Hasil penelitian ini menunjukkan bahwa kadar merkuri $(\mathrm{Hg})$ dalam perairan Sungai Tabobo belum melewati Nilai Ambang Batas sesuai Baku Mutu air.

\section{Kata Kunci: Sungai Tabobo, Merkuri (Hg), Parameter Kualitas Air dan Spektrofotometri Serapan Atom (SSA).}

\section{A. PENDAHULUAN}

\section{Latar Belakang}

Pencemaran atau polusi adalah suatu kondisi yang telah berubah dari bentuk asal pada keadaan yang lebih buruk. Pergeseran bentuk tatanan dari kondisi asal pada kondisi yang buruk ini dapat terjadi sebagai akibat masukan dari bahan-bahan pencemar atau polutan. Bahan polutan tersebut pada umumnya mempunyai sifat racun (toksik) yang berbahaya bagi organisme hidup. Toksisitas atau daya racun dari polutan itulah yang kemudian menjadi pemicu terjadinya pencemaran (Palar, 1994). Salah satu bahan pencemar yang sangat tinggi daya racunnya adalah merkuri $(\mathrm{Hg})$.

Pencemaran atau polusi adalah suatu kondisi yang telah berubah dari bentuk asal pada keadaan yang lebih buruk. Pergeseran bentuk tatanan dari kondisi asal pada kondisi yang buruk ini dapat terjadi sebagai akibat masukan dari bahan-bahan pencemar atau polutan. Bahan polutan tersebut pada umumnya mempunyai sifat racun (toksik) yang berbahaya bagi organisme hidup. Toksisitas atau daya racun dari polutan itulah yang kemudian menjadi pemicu terjadinya

pencemaran (Palar, 1994). Salah satu bahan pencemar yang sangat tinggi daya racunnya adalah merkuri $(\mathrm{Hg})$.

Merkuri (Hg) merupakan elemen alami, salah satu bahan pencemar logam berat yang banyak mencemari lingkungan dan bersifat sangat akumulatif toksik. Merkuri jarang sekali ditemukan dalam bentuk bebas. Di lingkungan, unsur ini terikat dengan unsur kimia lainnya yang tersebar di karang-karang, tanah, udara, air dan bahkan organisme hidup. Penyebaran merkuri ini turut dipengaruhi oleh faktor geologi, fisika, kimia dan biologi yang kompleks (Fardiaz, 1992; Palar 1994).

Sungai Tabobo merupakan sungai yang terdapat di kecamatan Malifut yang di sekitarnya terdapat pertambangan Emas yaitu tambang PT NHM (Nusa Halmahera Mineral) dan pertambangan secara tradisional yang dikelola oleh masyarakat.

Akibat dari kegiatan pertambangan emas yang dilakukan oleh pihak perusahaan swasta maupun penambang masyarakat sehingga diduga terjadi pencemaran disekitar ssungai Malifut yang akhirnya menuju ke teluk Kao yang ada disekitar Sungai. Hal ini diperkuat dengan pemberitaan Koran Kompas tahun 2011 yang menyatakan bahwa banyak
\end{abstract}


nelayan di pesisir Teluk Kao berhenti melaut karena hasil tangkapan ikan maupun udang sudah berkurang sehingga warga lebih mengandalkan kopra. Hal ini dipicu oleh pembuangan limbah pengolahan emas ke perairan setempat melalui Sungai disekitar Teluk Kao.

Berdasarkan hal tersebut di atas, maka penelitian menyangkut pencemaran logam berat merkuri menjadi sangat penting dilakukan mengingat dampak negatif yang ditimbulkan oleh limbah logam berat akan berpengaruh besar terhadap perairan maupun organisme hingga ke muara sungai Tabobo dan akan berpengaruh juga ke Teluk Kao.

\section{Rumusan Masalah}

a. Berapa besar kandungan bahan pencemar logam berat merkuri $(\mathrm{Hg})$ di sungai Tabobo?

b. Bagaimana keadaan kualitas air sungai Tabobo kecamatan Malifut kabupaten Halmahera Utara?

\section{Tujuan Penelitian}

a. Untuk mengetahui kandungan logam berat merkuri $(\mathrm{Hg})$ di sungai Tabobo kecamatan Malifut.

b. Untuk mengetahui kualitas air sungai Tabobo kecamatan Malifut kabupaten Halmahera Utara.

\section{B. LANDASAN TEORI}

\section{Pengertian Pencemaran}

Odum (1971) mengatakan bahwa pencemaran perairan adalah suatu perubahan fisika, kimia dan biologi yang tidak dikehendaki pada ekosistem perairan yang akan menimbulkan kerugian pada sumber kehidupan, kondisi kehidupan dan proses industri.

Pencemaran perairan pesisir didefinisikan sebagai dampak negatif, pengaruh yang membahayakan terhadap kehidupan biota, sumberdaya dan kenyamanan ekosistem perairan serta kesehatan manusia dan nilai guna lainnya dari ekosistem perairan yang disebabkan secara langsung oleh pembuangan bahan-bahan atau limbah ke dalam perairan yang berasal dari kegiatan manusia (GESAMP, 1986).

\section{Sumber Pencemaran}

Sumber pencemar dapat dibedakan menjadi sumber domestik (rumah tangga) yaitu dari perkampungan, kota, pasar, jalan, terminal, rumah sakit, dan sebagainya, serta sumber non domestik, yaitu dari pabrik, industri, pertanian, peternakan, perikanan, transportasi, dan sumber-sumber lainnya. Sedangkan bentuk pencemar dapat dibagi menjadi bentuk cair, bentuk padat, bentuk gas dan kebisingan (Tresna, 1991)

\section{Logam Berat}

Logam adalah unsur alam yang dapat diperoleh dari laut, erosi batuan tambang, vulkanisme dan sebagainya (Clark, 1986). Umumnya logam-logam di alam ditemukan dalam bentuk persenyawaan dengan unsur lain, sangat jarang yang ditemukan dalam elemen tunggal. Unsur ini dalam suhu kamar tidak selalu berbentuk padat melainkan ada yang berbentuk cair, misalnya merkuri $(\mathrm{Hg})$.

Merkuri atau air raksa mempunyai nama kimia hidragyrum yang berarti perak cair, disimbolkan dengan Hg (Palar, 1994). Sementara itu apabila diterjemahkan kedalam bahasa Indonesia, merkuri berarti mudah menguap (Rompas, 1992). Warna merkuri tergantung pada bentuk fasenya, pada fase cair berwarna putih perak, dan pada fase padat berwarna abu-abu.

Secara alamiah merkuri juga terdapat dalam lingkungan perairan dengan konsentrasi yang sangat kecil dan terdistribusi secara tidak merata (Hutagalung, 1985). Merkuri memasuki bagian perairan lewat endapan (kandungan air hujan 0,0008-1,45 $\mu \mathrm{g} / \mathrm{Hg}$ ) dan berupa lumpur atau larutan emisi dari kerusakan alami dan curahan antropogenik. Merkuri di atmosfir, biasanya terdiri dari $49 \%$ unsur bebas. $25 \%$ merkuri (II) Halida, 21\% monometil merkuri dan $1 \%$ uap dimetil merkuri serta $4 \%$ ikatan partikel merkuri.

Menurut Soelaiman (2000), penggunaan merkuri di dalam industri dapat mengakibatkan pencemaran lingkungan, baik melalui air limbah maupun melalui sistem ventilasi udara. Merkuri yang terbuang ke sungai, pantai atau badan air disekitar industri-industri tersebut dapat mengkontaminasi ikan dan makhluk air lainnya, termasuk ganggang dan tumbuhan air. Selanjutnya ikan-ikan kecil dan makhlukmakhluk air lainnya akan dimakan ikan atau hewan air lainnya yang lebih besar.

2. Dampak Pencemaran logam berat merkuri (Hg) Terhadap Lingkungan Perairan dan Organisme 
Keracunan yang disebabkan oleh merkuri ini, umumnya berawal dari kebiasaan memakan makanan dari laut, terutama sekali ikan, udang dan tiram yang telah terkontaminasi oleh merkuri. Awal peristiwa kontaminasi merkuri terhadap biota laut adalah masuknya buangan industri yang mengandung merkuri ke badan perairan teluk (lautan).

Selanjutnya dengan adanya proses biomagnifikasi yang bekerja di lautan, konsentrasi merkuri yang masuk akan terus ditingkatkan disamping penambahan yang terus menerus dari buangan pabrik. Merkuri yang masuk tersebut kemudian berasosiasi dengan sistem rantai makanan yang diambil dari perairan dan ikut termakan oleh manusia bersama makanan yang diambil dari perairan yang tercemar oleh merkuri (Palar, 1994).

\section{Parameter Kualitas Air}

a. Suhu

Suhu mempengaruhi aktifitas metabolisme organisme, karena itu penyebaran organisme baik di lautan maupun di perairan tawar dibatasi oleh suhu perairan tersebut. Suhu sangat berpengaruh terhadap kehidupan dan pertumbuhan ikan. Secara umum laju pertumbuhan meningkat sejalan dengan kenaikan suhu, dapat menekan kehidupan ikan bahkan menyebabkan kematian bila peningkatan suhu sampai ekstrem (drastis) (Kordi, 2005).

Nybakken (1988) menjelaskan bahwa suhu merupakan salah satu faktor yang sangat penting dalam mengatur proses kehidupan dan penyebaran organisme. Kaidah umum menyebutkan bahwa reaksi kimia dan biologi air (proses fisiologis) akan meningkat 2 kali lipat pada kenaikan temperatur $10^{\circ} \mathrm{C}$, selain itu suhu juga berpengaruh terhadap penyebaran dan komposisi organisme. Kisaran suhu yang baik bagi kehidupan organisme perairan adalah antara $18-30^{\circ} \mathrm{C}$.

\section{b. Salinitas}

Salinitas atau kadar garam air biasanya didefinisikan sebagai jumlah (dalam garam) dari total garam terlarut yang ada dalam 1 kilogram air laut dan biasanya diukur dengan konduktivitas. Semakin tinggi konduktifitas semakin tinggi kadar garamnya. Komposisi kadar garam tersebut selalu dalam keadaan yang konstan dalam jangka waktu yang panjang. Hal ini disebabkan karena adanya kontrol dari berbagai proses kimia dan biologi di dalam perairan laut. Kondisi ini menyebabkan sebagian besar organisme yang hidup diperairan laut merupakan organisme yang memiliki toleransi (sensitivitas) terhadap perubahan salinitas yang sangat kecil atau organisme yang diklasifikasikan sebagai organisme stenohalin (Widodo, 2006).

\section{c. pH (Derajat Keasaman)}

$\mathrm{pH}$ adalah istilah yang digunakan untuk menyatakan intensitas keadaan asam atau basa suatu larutan. $\mathrm{pH}$ juga merupakan suatu cara untuk menyatakan konsentrasi ion $\mathrm{H}$. Asam adalah senyawa yang menghasilkan ion hydrogen $(\mathrm{OH})$ bila dilarutkan dalam air, sedangkan basa adalah senyawa-senyawa yang menghasilkan ion hidroksil $\left(\mathrm{OH}^{-}\right)$. $\mathrm{H}$ dan $\mathrm{OH}^{-}$berasal dari ionisasi molekul $\mathrm{HO}$ (Soetomo H.A., 1990 dalam Kordi, 1996).

\section{d. DO (Oksigen Terlarut)}

Tresna (1991), dalam air deras biasanya oksigen tidak menjadi faktor pembatas. Dalam sungai yang jernih dan deras kepekatan oksigen mencapai kejenuhan. Jika air berjalan lambat atau ada pencemar maka oksigen yang terlarut mungkin dibawah kejenuhan, sehingga oksigen kembali menjadi faktor pembatas kepekatan oksigen terlarut bergantung kepada:

1) Suhu

2) Kehadiran tanaman fotosintesis

3) Tingkat penetrasi cahaya yang tergantung kepada kedalaman dan kekeruhan air,

4) Tingkat kederasan aliran air

5) Jumlah bahan organik yang di uraikan dalam air, seperti sampah, gangang mati, atau limbah industri.

\section{METODE PENELITIAN}

1. Rancangan Penelitian, Penelitian ini menggunakan metode analisis deskriptif kualitatif.

2. Alat dan Bahan, Alat dan bahan dalam penelitian ini dapat dilihat pada table berikut: 
Tabel 1.

Alat Dan Bahan Penelitian

\begin{tabular}{clcl}
\hline No & \multicolumn{1}{c}{ Alat/Bahan } & Satuan & \multicolumn{1}{c}{ Kegunaan } \\
\hline 1 & GPS & - & Menentukan koordinat \\
2 & Water quality checker & - & Mengukur pH, Turbidity, DO \\
3 & Coolbox & - & Tempat penyimpanan sampel \\
4 & Botol aqua & $\mathrm{ml}$ & Sebagai wadah sampel \\
5 & Hand Refractometer & $\mathbf{\% o}$ & Mengukur salinitas \\
6 & Termometer & ${ }^{\circ} \mathrm{C}$ & Untuk mengukur suhu perairan \\
7 & Aquades & $\mathrm{ml}$ & Untuk menetralisir alat \\
& Es batu $_{8}$ & - & Pengawet dingin (fisika) \\
8 & $\mathrm{H}_{2} \mathrm{SO}_{4}$ & $\mathrm{ml}$ & Pengawet Sampel air \\
9 & Perahu/katinting & pack & Mengeringkan alat \\
10 & Sampel air sungai dan laut & unit & Mengambil sampel dilaut \\
11 & Papan LJK & $\mathrm{ml}$ & Sebagai bahan uji di laboratorium \\
12 & Pena & - & Pengalas lembar data \\
13 & Dokumen rekaman & - & Untuk mencatat data \\
14 & Kamera & Lembar & Merekam data kerja di lokasi \\
15 & SSA Shimadzu & - & Dokumentasi \\
16 & Peta & Unit & Menganalisis sampel air \\
\hline
\end{tabular}

\section{Lokasi Penelitian}

Penelitian ini dilaksanakan di perairan Sungai Tabobo, Kecamatan Malifut, Kabupaten Halmahera Utara Propinsi Maluku Utara.

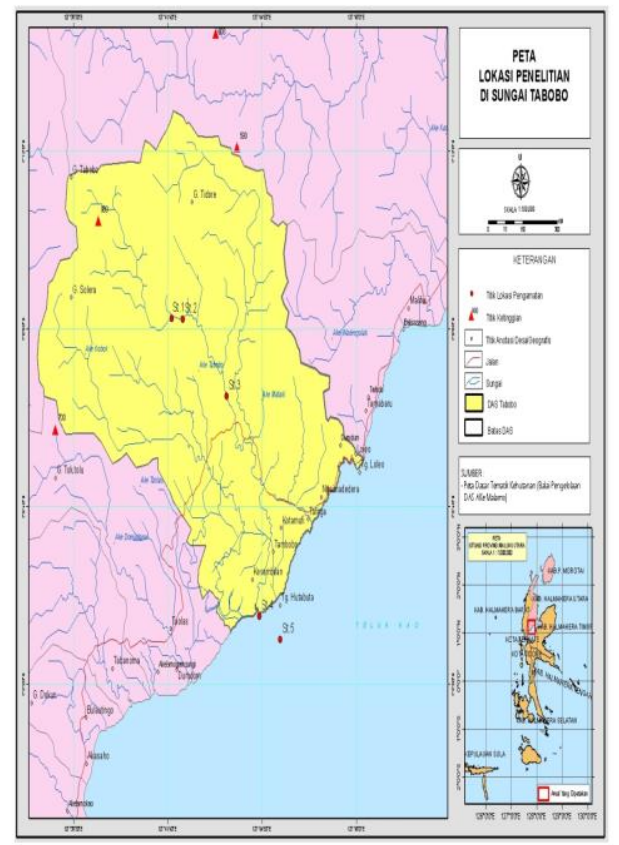

Gambar 1. Peta lokasi penelitian dan stasiun pengambilan sampel

\section{Teknik Pengambilan Sampel}

Penelitian ini dibagi dalam 5 stasiun. Masing-masing stasiun dilakukan pengukuran kualitas air seperti suhu, salinitas, DO, pH dan turbidity. Untuk pengukuran logam berat merkuri maka masing-masing stasiun diambil sampelnya kemudian sampel ini di bawah ke laboratorium untuk analisis dengan menggunakan spektrofotometrik serapan atom (SSA) yang di lakukan di laboratorium Balai Riset dan Standarisasi Industri (BARISTAND) Manado, menggunakan metode analisis SSA Tipe Shimadzu AA6200 dengan sampel air.

\section{HASIL DAN PEMBAHASAN}

\section{Analisis Kualitas Air}

Dalam rangka pengelolaan kualitas air dan atau pengendalian pencemaran air, perlu diketahui status mutu air (the state of the water quality). Untuk itu dilakukan pengukuran kualitas air guna mengetahui mutu air dengan membandingkannya dengan standar baku mutu air sesuai peraturan pemerintah yang berlaku. Untuk itu maka dilakukanlah pengukuran beberapa parameter lingkungan pada lokasi penelitian dengan hasil seperti pada table di bawah ini. 
Tabel 2.

Hasil Pengamatan Kualitas Air Di Tiap Stasiun

\begin{tabular}{cccccc}
\hline Stasiun & $\begin{array}{c}\text { Suhu } \\
{ }^{\circ} \mathrm{C}\end{array}$ & $\begin{array}{c}\text { Salinitas } \\
(\%)\end{array}$ & $\mathrm{pH}$ & $\begin{array}{c}\text { DO } \\
(\mathrm{ppm})\end{array}$ & Koordinat \\
\hline I & 25,7 & 0 & 7,5 & 9,81 & $\begin{array}{l}\text { N. } 01.15040 \\
\text { E. } 127.69657\end{array}$ \\
\hline II & 26 & 0 & 7,4 & 9,70 & $\begin{array}{l}\text { N. } 01.15006 \\
\text { E. } 127.70285\end{array}$ \\
\hline III & 26,3 & 0 & 7,4 & 9,52 & $\begin{array}{l}\text { N. } 01.12723 \\
\text { E. } 127.72746\end{array}$ \\
\hline IV & 28,5 & 15 & 7,1 & 8,47 & $\begin{array}{l}\text { N. } 01.06170 \\
\text { E. } 127.74572\end{array}$ \\
\hline V & 30 & 35 & 8,1 & 7,11 & $\begin{array}{l}\text { N. } 01.05487 \\
\text { E. } 127.75742\end{array}$ \\
\hline
\end{tabular}

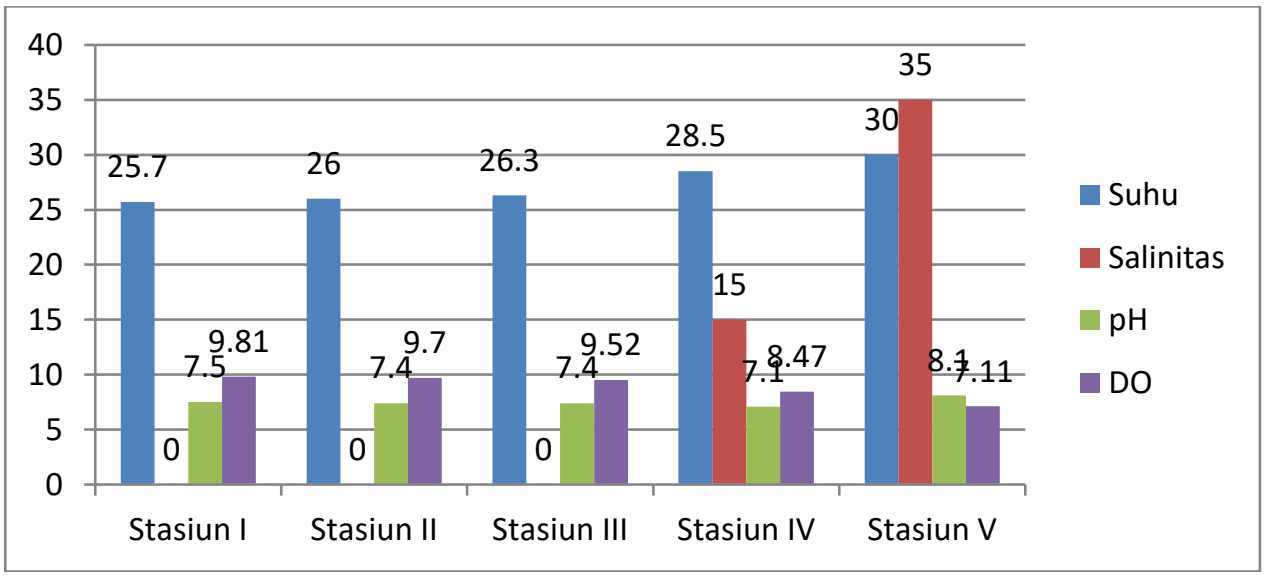

Gambar 2. Hasil Pengamatan kualitas air pada lokasi penelitian

\section{a. Suhu}

Berdasarkan Tabel di 2 atas terlihat bahwa suhu pada lokasi penelitian berkisar antara $25,7^{\circ} \mathrm{C}$ sampai $30^{\circ} \mathrm{C}$. Dimana suhu terendah diperoleh dari stasiun I dengan suhu $25,7^{\circ} \mathrm{C}$ dan suhu tertinggi diperoleh pada stasiun $\mathrm{V}$ dengan suhu $30^{\circ} \mathrm{C}$.

Berdasarkan pernyataan Nybakken (1998) bahwa kisaran suhu yang baik bagi kehidupan organisme perairan adalah antara 18-30 ${ }^{\circ} \mathrm{C}$ maka dapat disimpulkan bahwa suhu yang ditemukan pada lokasi penelitian masih sesaui untuk kehidupan organisme perairan.

\section{b. Salinitas}

Dari Tabel 2 diatas nampak bahwa kisaran salinitas yang diperoleh pada lokasi penelitian adalah berkisar antara 0-35 \%o. Stasiun I-III salinitas yang ditemukan $0 \%$, ini artinya bahwa pada stasiun tersebut belum terpengaruh oleh air laut atau belum ada percampuran dengan air laut. Dengan kata lain air pada ketiga stasiun tersebut masih tawar. Pada stasiun III salinitasnya sudah $15 \%$. Ini berarti sudah ada pengaruh air laut atau percampuran air tawar dengan air laut yang biasa juga disebut dengan dengan air payau. Sedangkan pada stasiun $\mathrm{V}$ salinitas yang ditemukan sudah mencapai 35 $\%$. Ini mengandung arti bahwa pada perairan ini sudah tidak ada pengaruh air tawar lagi.

c. $\mathbf{p H}$

pH yang ditemukan pada lokasi penelitian berkisisar antara 7,1-8,1. pH tertinggi diperoleh pada stasiun $\mathrm{V}$ dan terendah pada stasiun IV (Tabel 2). Berdasarkan baku mutu air menurut Kepmen LH No. 51 tahun 2004 mengatakan bahwa $\mathrm{pH}$ yang baik untuk mendukung kehidupan baik biota maupun organisme lainnya berkisar antara 6,5 8,5. Ini berarti bahwa $\mathrm{pH}$ yang ditemukan pada lokasi penelitian masih sesuai dengan stardar baku 
mutu air yang ditetapkan berdasarkan Kepmen LH No.51 tahun 2004.

\section{d. DO meter (oksigen terlarut)}

Oksigen terlarut ditemukan pada lokasi penelitian berdasarkan Table 2 di atas berkisar antara 7,77 - 9,8. DO tertinggi ditemukan pada stasiun I dan terendah pada stasiun V.

Berdsasarkan kandungan DO menurut Lee et al. (1978) yang mengelompokkan kualitas perairan atas empat tingkatan yaitu tidak tercemar $(>6,5 \mathrm{ppm})$, tercemar ringan (4,5 - 6,5 ppm), tercemar sedang $(2,0-4,4$ $\mathrm{ppm})$ dan tercemar berat $(<2,0 \mathrm{ppm})$.

Berdasarkan pengelompokan kualitas perairan yang dikemukakan oleh Lee et al., (19768), maka kadar oksigen terlarut pada lokasi penelitian masuk kategori tidak tercemar. Dan menurut Menteri Negara Lingkungan Hidup (MNLH, 2004) tentang baku mutu air laut untuk biota laut bahwa nilai oksigen terlarut yang diperbolehkan adalah lebih dari 5 ppm, maka kada oksigen terlarut yang diperoleh pada lokasi penelitian menunjukkan bahwa masih layak untuk kehidupan biota laut.

\section{Analisis Logam Berat Merkuri (Hg)}

Hasil analisis kandungan logam berat merkuri $(\mathrm{Hg})$ berdasarkan spektrofotometri serapan atom (SSA) dengan satuan $\mathrm{ppb}$, di dapatkan nilai yang berkisar antara 0,0025 0,0073 ppb. Hasil analisis logam berat merkuri dapat dilihat pada Table 3 di bawah ini.

Tabel 3.

Merkuri (Hg) Dengan Satuan ppb

\begin{tabular}{llccccccc}
\hline & & \multicolumn{9}{c}{ Hasil Analisis } & & \\
\cline { 2 - 6 } No. & Parameter & $\begin{array}{c}\text { Stasiun } \\
\text { I }\end{array}$ & $\begin{array}{c}\text { Stasiun } \\
\text { II }\end{array}$ & $\begin{array}{c}\text { Stasiun } \\
\text { III }\end{array}$ & $\begin{array}{c}\text { Stasiun } \\
\text { IV } \\
\text { (Muara) }\end{array}$ & $\begin{array}{c}\text { Stasiun } \\
\text { V (Laut) }\end{array}$ & Satuan & $\begin{array}{c}\text { Metode } \\
\text { Analisis }\end{array}$ \\
\hline 1 & $\mathrm{Hg}$ & 0,0025 & 0,0043 & 0,0045 & 0,0056 & 0,0073 & ppb & AAS \\
\hline
\end{tabular}

Dari Tabel 3 di atas terlihat bahwa konsentrasi merkuri tertinggi diperoleh pada stasiun $\mathrm{V}$ dengan tingkat konsentrasi merkuri sebesar $0,0073 \mathrm{ppb}$ dan terendah pada stasiun I dengan kandungan merkuri sebesar 0,0025 ppb.
Berdasarkan criteria baku mutu air yang baik adalah tidak lebih dari $0,0014 \mathrm{ppb}$ atau $0,002 \mathrm{mg} / \mathrm{l}$ maka dapat disimpulkan bahwa pada lokasi penelitian masih belum tercemar oleh bahan logam berat merkuri $(\mathrm{Hg})$. Hal ini dapt dilhat pada table di bawah ini.

Tabel 4.

Standar Baku Mutu Air Terhadap Logam Berat Merkuri

\begin{tabular}{cccc}
\hline Stasiun & Merkuri $(\mathrm{mg} / \mathrm{l})$ & Merkuri $(\mathrm{ppb})$ & Standar Baku \\
\hline I & 0,00 & 0,0025 & \\
II & 0,00 & 0,0043 & \\
III & 0,00 & 0,0045 & $0,002 \mathrm{mg} / \mathrm{l}^{(1)}$ atau $0,0014 \mathrm{ppb}^{(2)}$ \\
IV & 0,00 & 0,0056 & \\
V & 0,00 & 0,0073 & \\
\hline
\end{tabular}

Keterangan:

1) PP Nomor 82 Tahun 2001

2) Environmental Protection Agency. 1973. Water quality criteria

\section{E. KESIMPULAN DAN SARAN}

\section{Kesimpulan}

Berdasarkan hasil dan pembahasan dapat ditarik kesimpulan sebagai berikut: a. Bahan pencemar logam berat merkuri $(\mathrm{Hg})$ di perairan Sungai Tabobo masih berada di bawah Nilai Ambang Batas.

b. Kualitas perairan Sungai Tabobo di tinjau dari parameter fisika-kimia umumnya 
masih layak bagi kehidupan organisme perairan.

2. Saran

Perlu dilakukan penelitian lanjutan tentang konsentrasi merkuri (Hg) pada sedimen di Sungai Tabobo, Kecamatan Malifut untuk memperoleh hasil yang lebih lengkap.

\section{DAFTAR PUSTAKA}

Clark, R.B., 1986. Marine Pollution. Claredon Press, Oxford.

EPA (Environmental Protection Agency, 1973. Water Quality Criteria, Ecological Research Series, Wasington.

Fardiaz, S., 1992. Polusi Air dan Udara. Kanisius, Yoguakarta.

GESAMP (Group Expert on Scientific Aspect of Marine Pollution), 1986. Report of The Seven Session, WHO (World Health Organisation).

Hutagalung, H.P., $1985 . \quad$ Pengaruh Pencemaran Logam Berat Terhadap Biota Laut. Kerjasama dengan UNECO-UNDIP. Jakarta.

Kordi, M.G.H. 1996. Parameter Kualitas Air. Karya Andi, Surabaya

Lee, C.D.., S.B. Wang and C.L. Kuo, 1978. Benthic Macroinvertebrate and Fish as Biological Indicator of Water Quality, with Reference to Community Diversity Index dalam E.A.R. Guano, B.N. Lokani and M.C. Thank (Ed). Water Pollution Control in Developing Countries, Asian Inst. Tech. Bang-kok. $\mathrm{P}: 233-238$.

Menteri Negara Lingkungan Hidup (MNLH), 2004. Keputusan Menteri Negara Lingkungan Hidup No. 51/2004 Tentang Baku Mutu Air Laut untuk Biota Laut. KLH, Jakarta.

Nybakken, J., 1988. Biologi Laut: Suatu Pendekatan Ekologis. Gramedia, Jakarta.

Odum, E.P., 1971. Fundamental of Ecology. $3^{\text {rd }}$ Edition.W.B. Sounders Company, Philadelphia.

Palar, H., 1994. Pencemaran dan Toksikologi Logam Berat. Rineka Cipta, Jakarta.
PP No. 82 Tahun 2001 tentang Pengelolaan Kualitas Air dan Pengendalian Pencemaran, Jakarta.

Rompas, R.M., 1992. Toksikologi Kelautan. Bahan Kursus Pemantauan Pencemaran Laut, Kerjasama UNSRAT, P3O-LIPI dan Unesco. Manado.

Soelaiman, I., 2000. Siklus Logam Berat Merkuri di Alam. Makalah (Dalam Bidang Toksikologi dan Farmasetika Kelauan. Manado.

Tresna, S.A., 1991. Pencemaran Lingkungan. Rineka Cipta. Jakarta

Widodo, J., dan Suadi, 2006. Pengelolaan Sumberdaya Perikanan Laut.Gajah Mada University Press, Yogyakarta. 